\title{
OBSERVATIONS ON COCHLODESMA PRAETENUE (PULTENEY) [EULAMELLIBRANCHIA]
}

\author{
By J. A. Allen \\ Dove Marine Laboratory, Cullercoats
}

(Text-figs. I-I2)

Cochlodesma praetenue is the sole British species of the family Laternulidae included in the suborder Anomalodesmata (Thiele, 1935). Shell characters clearly distinguish this suborder from the remainder of the Eulamellibranchia. These characters include a thin, fragile, white shell that is usually inequivalve, hinge teeth that are weak or absent and a ligament that is well developed, complex and may include a lithodesma. Further, Yonge (1952) and Allen (1954) showed that the shell valves may be united dorsally by the periostracum and that some members of the group incorporate sand grains in the periostracum. Work by Ridewood (1903) and Atkins (1937 $a, b)$ and more recently by Yonge (1952) and Allen (1954) on the anatomy of members of the Anomalodesmata also shows other distinguishing characters, notably in the form of the ctenidia and of the stomach.

Knowledge of the functional morphology of the suborder is confined to the families Lyonsiidae, Pandoridae and Thraciidae. When C. praetenue was found to be obtainable in numbers from the Northumberland coast, advantage was taken to examine a member of another family of the Anomalodesmata and to compare it with related forms.

\section{HABITAT}

Cochlodesma praetenue is distributed from Iceland and the southern part of Norway to the Mediterranean (Forbes \& Hanley, I853). It is recorded from all British waters except the southern North Sea. It occurs in fine gravel, sand and muddy sands from extreme low-water mark of spring tides to a depth of 60 fathoms. It is most commonly found in sand and sandy-gravel in sheltered conditions just below the level of low water of spring tides. Specimens for this present study were taken in such a habitat from a beach at Low Newton on the Northumberland coast.

The common species of the associated infauna were: Nephthys hombergi Lam., Lanice conchilega (Pallas), Ampelisca brevicornis (A. Costa), Tellina fabula Gmelin, Venus striatula da Costa, Phacoides borealis (Linné), Ensis siliqua (Linné) and Echinocardium cordatum (Pennant). Cochlodesma is buried 
to a depth of $7 \mathrm{~cm}$ below the surface of the substratum and usually lies in a horizontal plane. Allowed to burrow in its normal substratum in aquarium tanks the animal comes to lie horizontally on either valve, slight preference being shown for the left side to be uppermost.

\section{Mantle/shell}

\section{MORPHOLOGY AND FUNCTIONS}

The thin shell valves are white and slightly inequivalve. The right valve is more convex than the left and overlaps it slightly. The margins of the valves are sinuate (Fig. I). Except for an area posterior to the umbonal ridge the shell is smooth. Posterior to the umbonal ridge the shell is roughened by numerous small pustules. Fine sand grains adhere to the roughened surface and make the shells conspicuous in sievings of sand samples. Unlike Lyonsia and Pandora the grains are not incorporated within the periostracum but lie on the surface and are kept in position by the roughness alone.

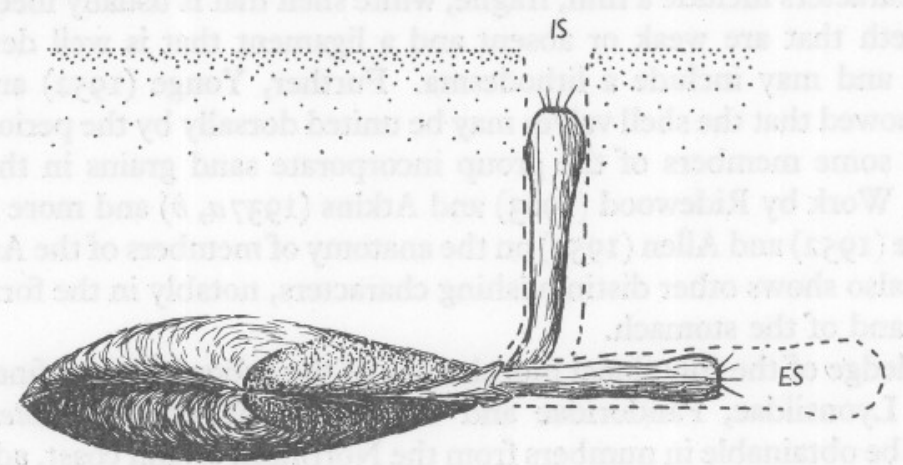

Fig. r. Cochlodesma praetenue in its normal position with the siphons extended. $E S$, exhalant siphon; $I S$, inhalant siphon.

Hinge teeth are not present. The ligament is complex and unusual, and is composed of an internal and an external portion. The internal portion of the ligament is held between a pair of spoon-shaped extensions of the shell which are carried at the end of a pronounced internal ridge that runs forward from the anterior edge of the posterior adductor muscle scar (Fig. 2). The internal portion of the ligament is wedge-shaped and is composed of three layers. The latter probably correspond with the outer, inner and fusion layers of Owen, Trueman \& Yonge (1953) and are referred to as such in the following account. The tip of the wedge connects with the external part of the ligament which, apart from a pair of small wing-like extensions of the inner layer, is composed entirely of fusion layer and its covering of periostracum (Fig. $3 \mathrm{~A}, \mathrm{~B}$ ). This external part extends for some distance anterior and posterior to the umbones and at the junction of the internal and external portions there is a lateral extension of the fusion layer that follows the line of the umbonal ridge 


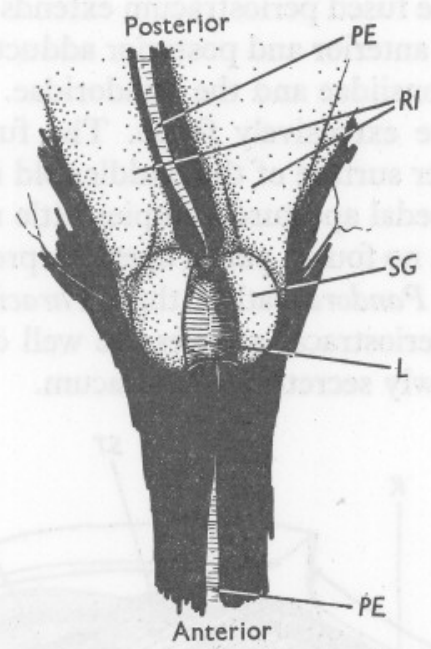

Fig. 2. The hinge mechanism as seen from the inside of the valves showing the terminal spoonshaped extensions $(S G)$ of the ridge $(R I)$ holding the ligament $(L)$. The valves are united dorsally by the periostracum $(P E)$.
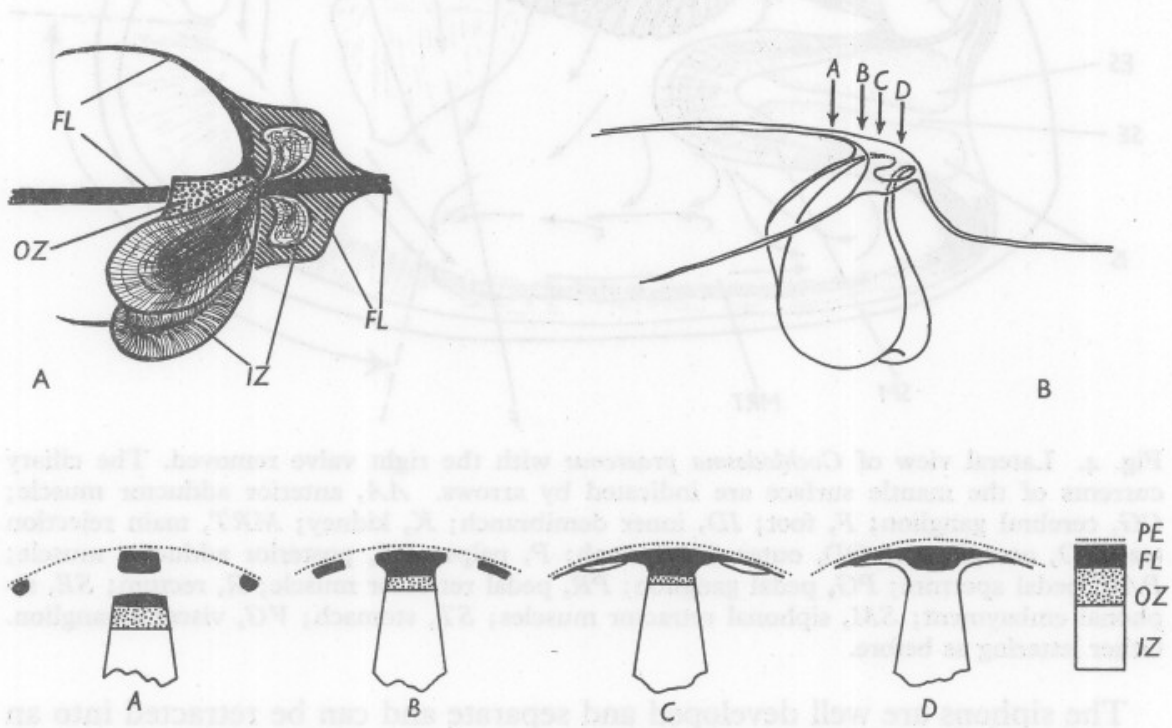

Fig. 3. A. The ligament as seen from the ventral side. The inner portion has been inclined to the side. $F L$, fusion layer; $I Z$, inner layer; $O Z$, outer layer. B. Outline drawing of the ligament in side view with arrows indicating the position of four transverse sections, $A, B, C$ and $D$. The latter are drawn diagrammatically. Lettering as before. 
(Fig. 3A, B). Dorsally the fused periostracum extends beyond the limits of the fusion layer as far as the anterior and posterior adductor muscles and parallels the condition in the Lyonsiidae and the Pandoridae.

The mantle edges are extensively fused. The fusion involves the inner mantle fold and the inner surface of the middle fold in the manner described by Yonge (I957). The pedal aperture occupies little more than a third of the ventral margin. There is no fourth pallial aperture present, and in this respect Cochlodesma resembles Pandora rather than Thracia and Lyonsia. Unlike those of Pandora, the periostracal grooves are well defined, and sand grains do not adhere to the newly secreted periostracum.

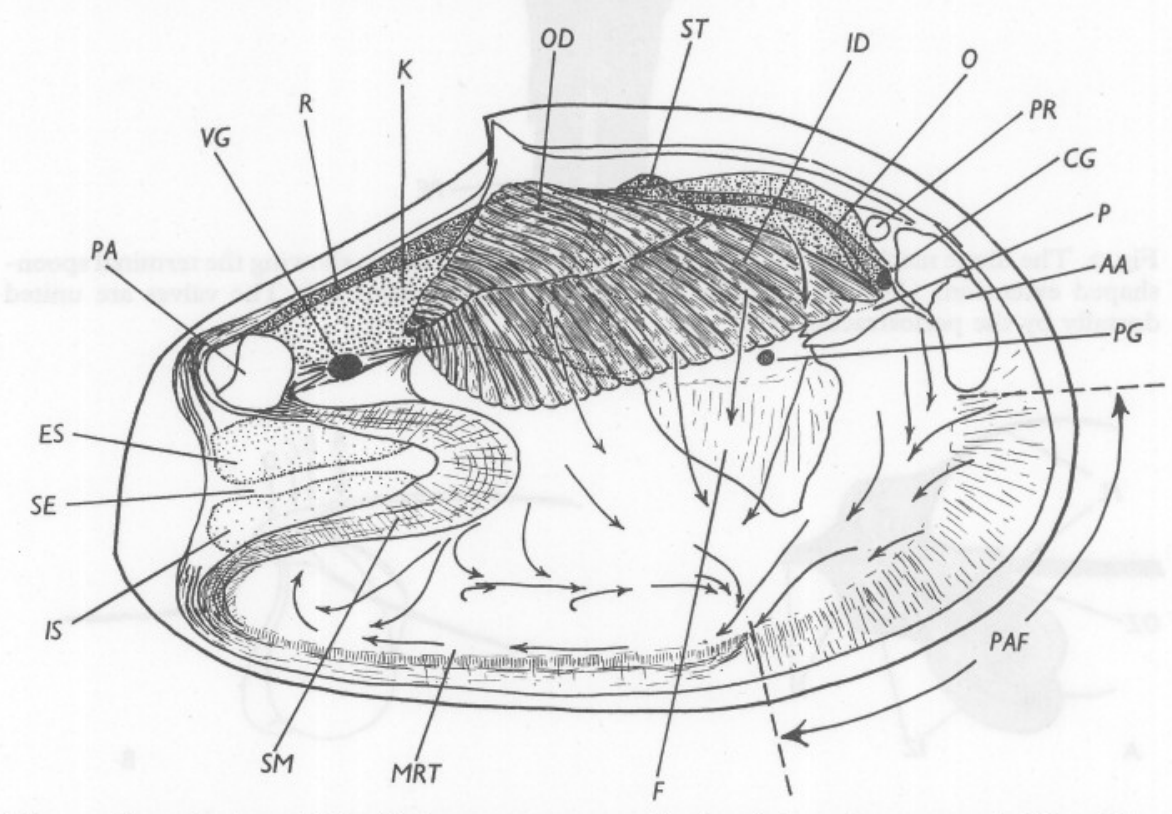

Fig. 4. Lateral view of Cochlodesma praetenue with the right valve removed. The ciliary currents of the mantle surface are indicated by arrows. $A A$, anterior adductor muscle; $C G$, cerebral ganglion; $F$, foot; $I D$, inner demibranch; $K$, kidney; $M R T$, main rejection tract; $O$, oesophagus; $O D$, outer demibranch; $P$, palps; $P A$, posterior adductor muscle; $P A F$, pedal aperture; $P G$, pedal ganglion; $P R$, pedal retractor muscle; $R$, rectum; $S E$, siphonal embayment; $S M$, siphonal retractor muscles; $S T$, stomach; $V G$, visceral ganglion. Other lettering as before.

The siphons are well developed and separate and can be retracted into an extensive siphonal embayment (Figs. I, 4). They are formed from the inner fold of the mantle and can expand to more than twice the length of the shell. Each siphon can expand and contract independently of the other. Separate mucus-lined tubes are formed by the siphons. The tubes are similar to those of Thracia (Yonge, I937), but whereas in Thracia both tubes open to the surface only the inhalant tube does so in Cochlodesma. The exhalant tube 
extends horizontally into the substratum for a distance approximately equal to the depth the shell is buried. The mucous linings are less robust than those of Thracia and a complete tube was never separated from the substratum. Inflation of the distal ends of the siphons is not as marked as in the case of Thracia. Some inflation occurs for the purpose of consolidating the mucous secretion. Observations on tubes built against the sides of glass containers show that on completion of the tube the siphons do not completely retract, but remain extended for a few millimetres beyond the valve margins. No further extension of the siphon occurs except for the repair of the tube. Under experimental conditions Cochlodesma does not remain in the same position for

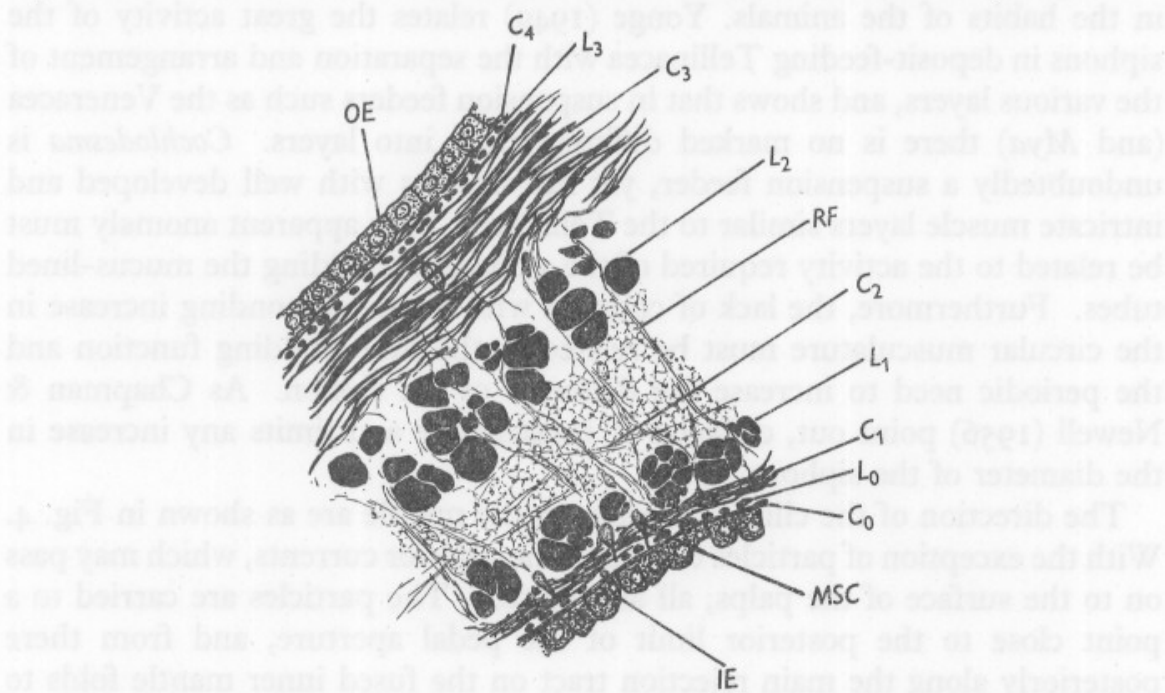

Fig. 5. Transverse section through a siphon to show the arrangement of the various layers. $C_{0}-C_{4}$, circular muscle layers; $I E$, inner epithelium; $L_{0}-L_{3}$, longitudinal muscle layers; $M S C$, mucus-secreting cells; $O E$, outer epithelium; $R F$, radial muscle fibres.

long periods of time, new tubes being built every $\mathrm{I2}-72 \mathrm{~h}$. This differs from the Lucinacea (Allen, 1953) which also build a mucus-lined tube yet remain in the same position for considerable periods of time. Unlike Thracia (Yonge, I937), there is no concentration of mucus-secreting cells at the distal end of the siphons, secretion taking place along their whole length in Cochlodesma.

The siphons elongate smoothly and expand and contract when the terminal aperture is either open or closed. No definite pattern of movement was observed. It appears that expansion is not necessarily a result of pressure on the water in the mantle cavity, a method described for Mya (Chapman \& Newell, 1956). The histology of the siphons of Cochlodesma is similar to that of the Tellinacea (Yonge, 1949; Chapman \& Newell, 1956) (Fig. 5), and they expand in a way similar to that described by Chapman \& Newell for Scrobicularia plana. Trichrome staining shows that there is much more circular 
muscle and less collagen in Cochlodesma than in the latter species and no lattice work of collagen was demonstrated. In Fig. 5 the nomenclature of the various muscle layers corresponds with that given by Yonge (1949) for the Tellinacea, the only differences being the presence of additional layers $L_{0}$ and $C_{0} . C_{2}$ is not well defined and a parenchymatous packing tissue fills the space between layers $L_{1}$ and $L_{2}$. Thus, the arrangement of the muscle layers is the same on either side of the central packing tissue. Well-defined nerve strands, four in the inhalant and six in the exhalant siphon, run through the central tissue, and supply four to eight simple tentacles at the aperture edge.

It is possible to correlate siphon structure in lamellibranchs with differences in the habits of the animals. Yonge (1949) relates the great activity of the siphons in deposit-feeding Tellinacea with the separation and arrangement of the various layers, and shows that in suspension feeders such as the Veneracea (and Mya) there is no marked differentiation into layers. Cochlodesma is undoubtedly a suspension feeder, yet has siphons with well developed and intricate muscle layers similar to the Tellinacea. This apparent anomaly must be related to the activity required of the siphons in building the mucus-lined tubes. Furthermore, the lack of collagen with the corresponding increase in the circular musculature must be related to the tube-building function and the periodic need to increase the diameter of the siphon. As Chapman \& Newell (1956) point out, collagen is inextensible and limits any increase in the diameter of the siphons.

The direction of the ciliary currents on the mantle are as shown in Fig. 4. With the exception of particles carried in the anterior currents, which may pass on to the surface of the palps, all are rejected. The particles are carried to a point close to the posterior limit of the pedal aperture, and from there posteriorly along the main rejection tract on the fused inner mantle folds to a point ventral to the inhalant aperture. Unlike Pandora, there is no mantle fold forming a roof over the main rejection tract. Apart from scattered mucus-secreting cells, the only concentration of glandular tissue in the mantle is close to the posterior apertures over the area of insertion of the siphonal retractor muscles. The elongate cells are modified epidermal cells and it is probable that their secretion is used in the formation of the pseudofaeces.

\section{Viscera}

The ciliary currents over the surface of the body are concerned with the rejection of particles. There is a main tract from the palps to the heel, and particles from the remainder of the body surface move posteriorly towards this tract. Apart from a narrow strip at the ventral edge, the foot is not ciliated (Fig. 6).

The viscera can be seen through the body wall. Gonads and digestive diverticula are compact and, as in most members of the Anomalodesmata, 
Cochlodesma is hermaphrodite. The ovaries lie posterior to the long axis through the style sac and stomach, the digestive diverticula being anterior to this line. The testes are placed between the digestive diverticula and the musculature of the foot. The course of the alimentary canal is also seen through the body wall as shown in Fig. 6. The kidney, although elongate, is similar to that of other Eulamellibranchia. The large visceral ganglion, instead of lying close to the posterior adductor muscle, is some distance anterior to the muscle below the kidney. This is probably correlated with the considerable depth of the siphonal embayment, the siphonal nerve having a short and direct route between the ganglion in this position and the base of the siphon.

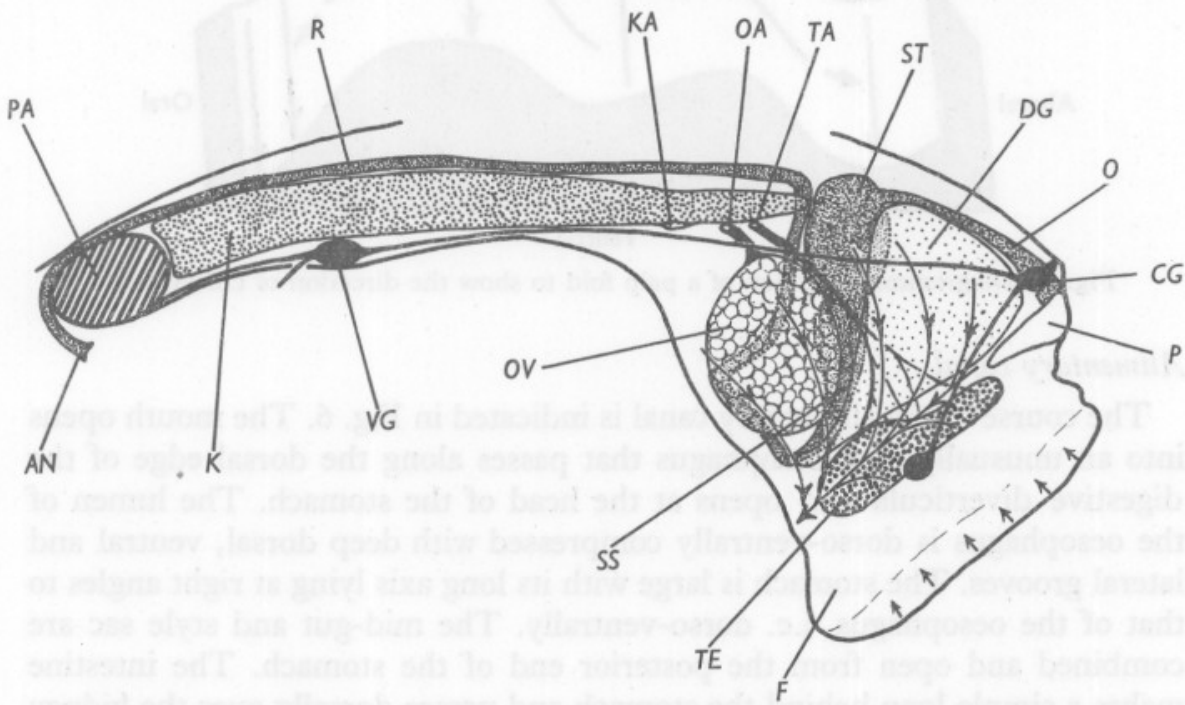

Fig. 6. View of the right side of the body to show the arrangement of the viscera and the direction of the ciliary currents on the body surface. $A N$, anus; $D G$, digestive diverticula; $K A$, renal aperture; $O A$, female genital pore; $O V$, ovary; $S S$, style sac; $T A$, male genital aperture; $T E$, testis. Other lettering as before.

\section{Gills}

The gills are typical of the Anomalodesmata with the outer demibranch reduced and reflected dorsally. They are deeply plicate ( 9 filaments/plica). Occasional specimens have the first I5-20 filaments non-plicate. The ciliary sorting mechanisms are of the Pinna type (Atkins, 1937a). All particles reaching the gill surface are carried to the marginal groove of the inner demibranch. Atkins (I937a, p. 349) figures the margin of the inner demibranch of Cochlodesma praetenue and the present work confirms her observations. The terminal frontal cilia are not modified to form a sorting device of the type described in Pandora (Allen, 1954). The gills are short and terminate anterior to the posterior adductor muscle (Fig. 4). 
Palps

The palps are strap-shaped and small. The sorting folds of the inner surface are relatively broad because of the unusual breadth of the shelf on the aboral side of the fold (Fig. 7). The ciliation shows no significant difference from the basic eulamellibranch type and the palps function in the typical manner.

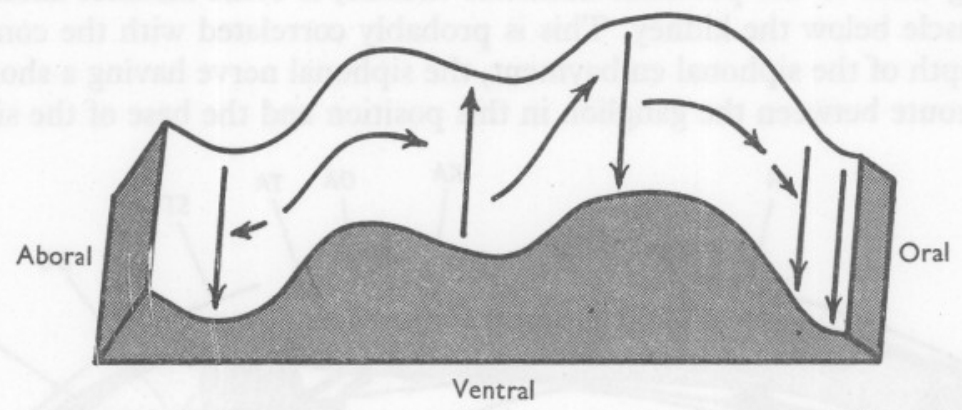

Fig. 7. Diagrammatic section of a palp fold to show the direction of ciliary beat.

\section{Alimentary canal}

The course of the alimentary canal is indicated in Fig. 6. The mouth opens into an unusually long oesophagus that passes along the dorsal edge of the digestive diverticula and opens at the head of the stomach. The lumen of the oesophagus is dorso-ventrally compressed with deep dorsal, ventral and lateral grooves. The stomach is large with its long axis lying at right angles to that of the oesophagus, i.e. dorso-ventrally. The mid-gut and style sac are combined and open from the posterior end of the stomach. The intestine makes a simple loop behind the stomach and passes dorsally over the kidney and the posterior adductor muscle to open at the anus.

The stomach was studied in some detail as earlier work on the related genus Pandora (Allen, I954) showed differences from the stomachs of other eulamellibranchs. By dissection and serial sections the morphology and ciliary currents of the stomach were investigated. The nomenclature of Owen (1953, I955) has been followed.

The stomach of Cochlodesma is similar to that of Pandora (Figs. 8, 9. Distortion in Fig. 8 has been confined largely to the gastric shield). Accepted particles entangled in a string of mucus are pulled into the stomach by the capstan-like action of the style. The average time taken for one revolution of the style was recorded for twenty-one specimens. In three (at $16.5^{\circ} \mathrm{C}$ ) the time for one revolution was $3.2 \mathrm{sec}$. In the remaining eighteen specimens (at $17^{\circ} \mathrm{C}$ ) the time varied from 2.6 to $4.9 \mathrm{sec} / \mathrm{rev}$., eleven records lying between 3.2 and $3.8 \mathrm{sec} / \mathrm{rev}$. The style rotates in a clockwise direction when viewed from the oesophageal end of the stomach. It is prevented from 
entering the dorsal hood by the tooth of the gastric shield (Fig. 10). Typically the shield is held in position by flanges penetrating the left pouch and the dorsal hood. The morphology and ciliary currents are basically similar to those of Pandora (Allen, 1954). In Cochlodesma the dorsal hood is well developed. The acceptance tract, terminating in a pad of tissue anterior to the end of the minor typhlosole, is considerably wider than that of Pandora. The posterior extension of the posterior sorting area is developed as a blind

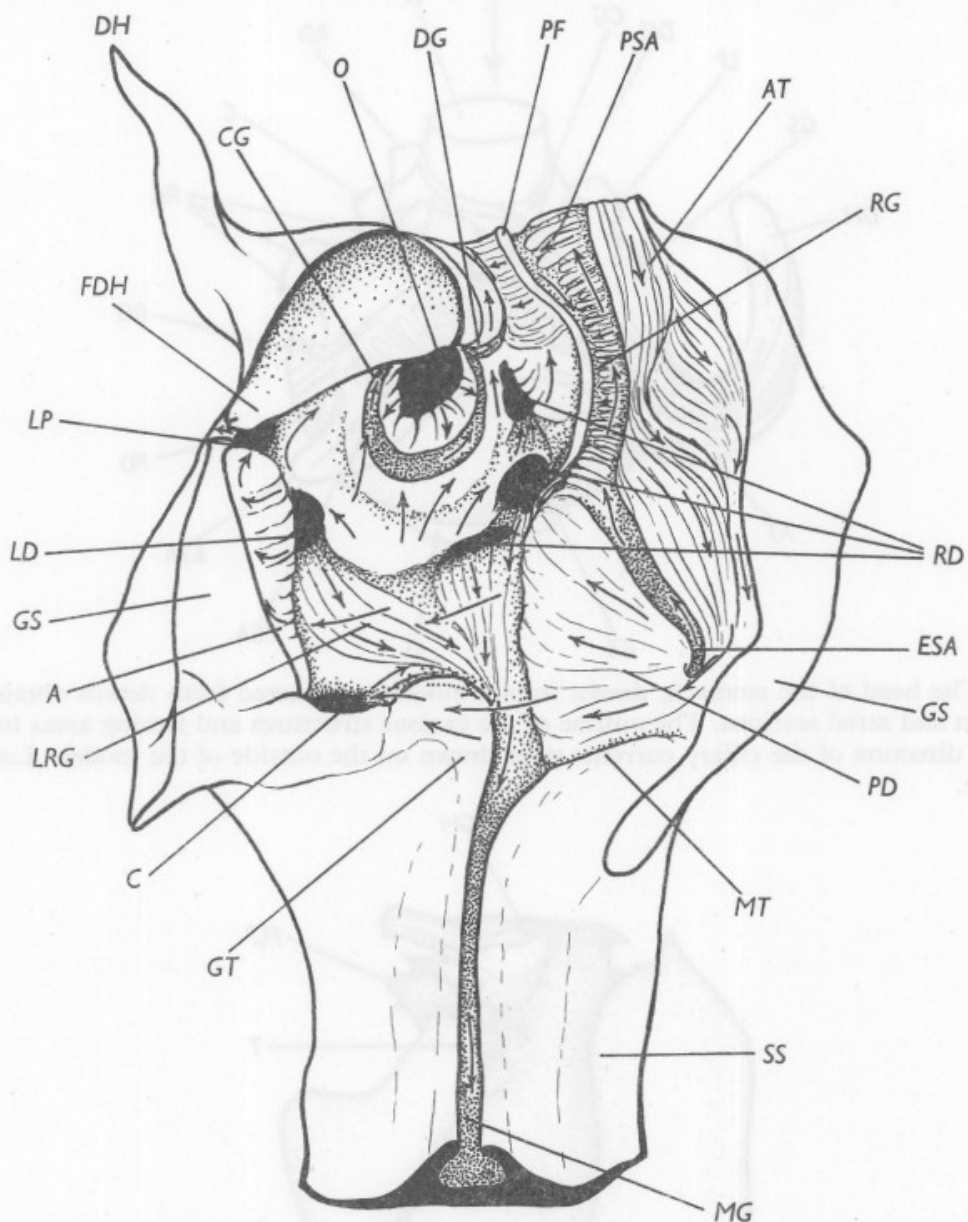

Fig. 8. The stomach dissected by a longitudinal cut through the centre of the gastric shield. The dorsal hood has not been opened. The direction of the ciliary currents are shown. $A$, collecting area; $A T$, acceptance tract; $C$, caecum; $C G$, circular groove; $D G$, dorsal groove; $D H$, dorsal hood; $E S A$, extension of the posterior sorting area; $F D H$, dorsal hood flange of the gastric shield; $G S$, gastric shield; $G T$, major typhlosole; $L D$, isolated left aperture; $L P$, left pouch; $L R G$, lateral rejection grooves; $M G$, mid-gut; $M T$, minor typhlosole; $P D$, pad; $P F$, posterior fold; $P S A$, posterior sorting area; $R D$, isolated right ducts; $R G$, rejection groove. Other lettering as before. 
pocket. The walls of this extension are without ridges and all particles on them are carried forward to the posterior sorting area. The extension is adjacent to a constriction in the acceptance tract where the latter fans out as a pad of tissue, described above. It is probable that this constriction controls the size of the particles passing on to the pad, and so to the apertures of the digestive diverticula. Particles wider than the constriction contact the strongly beating

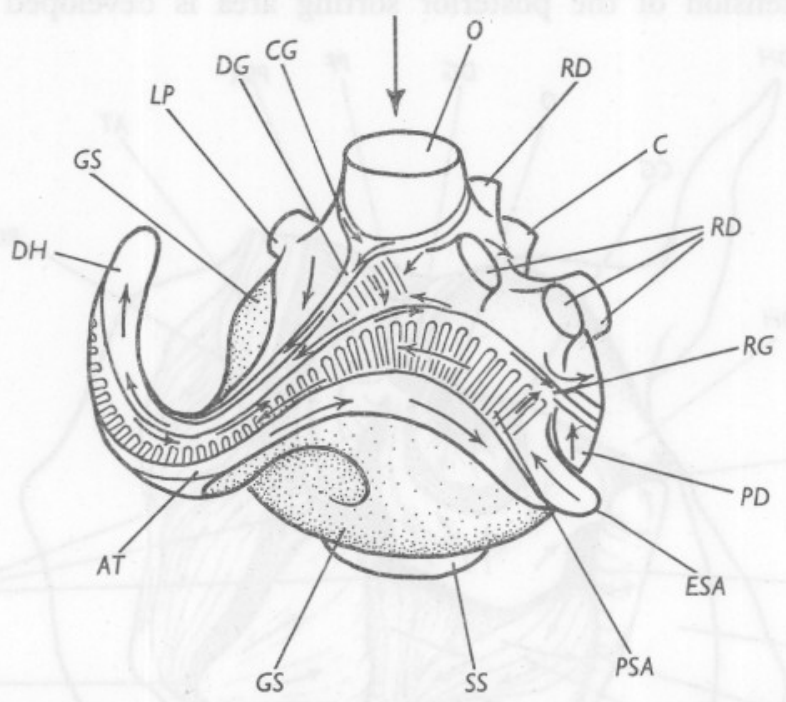

Fig. 9. The head of the stomach, drawn from a model constructed from details obtained by dissection and serial sections. The outline of the various structures and sorting areas together with the direction of the ciliary currents were drawn on the outside of the model. Lettering as before.

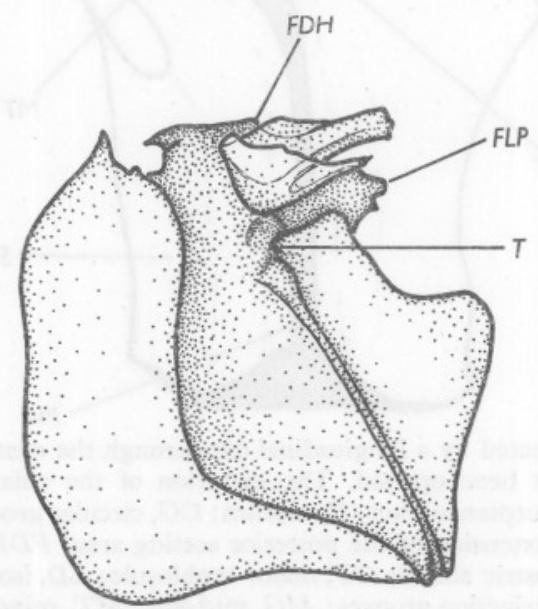

Fig. Io. Drawing of the gastric shield removed from the stomach. FLP, left pouch flange of the gastric shield; $T$, tooth. Other lettering as before. 
cilia of the extension and are diverted to the posterior sorting area. The replacement of an intestinal groove by a series of grooves (lateral rejection grooves) as was first described in Pandora, also occurs in Cochlodesma. The lateral rejection grooves extend from the apertures of the digestive diverticula to the mid-gut opening. In the depths of the grooves rejected material from the diverticula is carried to the mid-gut, while accepted material circulating in the stomach is carried across the grooves by the action of the cilia of the crests between the grooves.

The extent of the major typhlosole in Cochlodesma is also similar to that in Pandora. The typhlosole terminates in the entrance of what is probably the right caecum. In the description of Pandora (Allen, I954) the possibility that the opening immediately posterior to the left pouch (present in Cochlodesma) is homologous to the left caecum is discussed. While the arguments still hold in the case of Cochlodesma, Purchon, in a personal communication, has suggested that there is possibly only the one caecum and that the opening on the left side, posterior to the left pouch, is comparable to the isolated ducts of the right side-even though several ducts open at this one aperture.

Apart from these divergences the basic pattern of circulation of particles in the stomach is as described by Owen (1953, 1955) for other Eulamellibranchia.

\section{Digestive diverticula}

The organization of the digestive diverticula is similar to that of other lamellibranchs (Yonge, I926; Owen, 1955). They form a compact organ anterior to the stomach (Fig. 6) composed of main and secondary ducts and tubules. The main ducts are short and similar in cross-section to those of Zirphaea crispata (Owen, I955) (Fig. II A). The lumen is deeply grooved, the number of grooves varying from four to seven. A single ciliated tract is present. Main and secondary ducts do not differ histologically from those of other Eulamellibranchia (Owen, I955).

The digestive tubules, clustered at the distal end of each secondary duct, are elongate (Fig. I I B). They are unusual in that there are a number of minor branches along the length of each tubule. Each minor branch terminates at a single, large cell filled with a clear fluid. Non-ciliated crypt cells are situated close to this large cell and the remainder of the tubule is lined with typical vacuolated cells. Similar large cells have been reported in Lasaea rubra by Oldfield (1955) and Morton (1956) and in the Lucinacea (Allen, in the press). It is possible that, if the suggestion (Owen, 1955) that fluid is drawn into the tubule by the absorptive function of the cells is correct, these large cells carry out the major part of the absorption. Their terminal position and large size, almost entirely filled with a single vacuole containing a fluid and no particulate matter, suggests that this may well be the case, digestive function being confined to the vacuolated cells. 


\section{SIZE AND AGE GROUPS}

On three occasions Cochlodesma was obtained in sufficient numbers to give information on the age and size grouping of the Newton population. Shell markings give no indication of age and annual growth rate. The sieve used (aperture size $3 \mathrm{~mm}^{2}$ ) did not retain shells less than $5 \mathrm{~mm}$ long, and examination of material not retained by it showed that one size-group had passed through in each of the samples. The approximate average length of this group

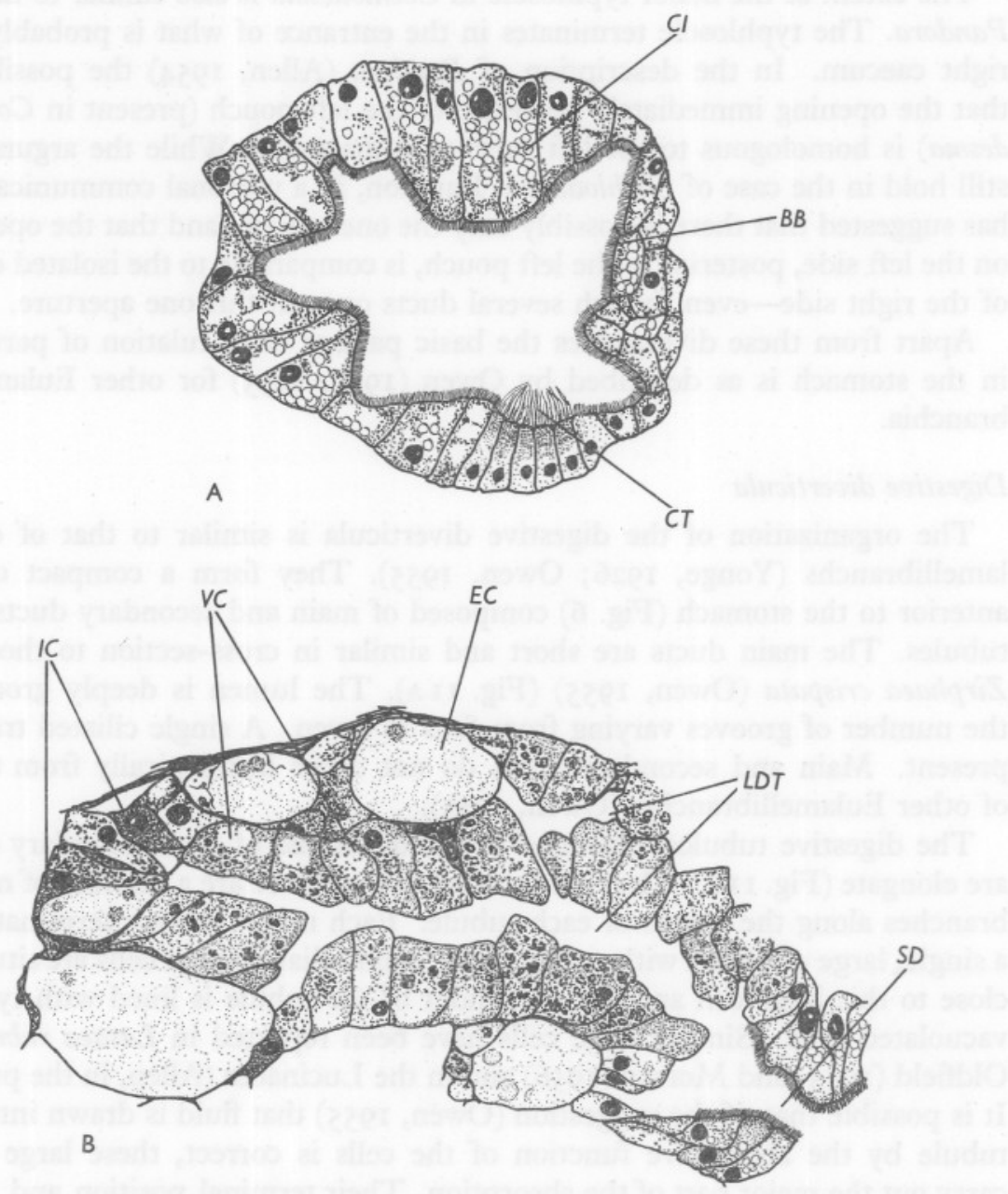

Fig. II. A. Transverse section of a main duct of the digestive diverticula. $B B$, brush border; $C I$, refractive cell inclusions; $C T$, ciliated tract. B. Longitudinal section of a tubule to show the minor branching. $E C$, large terminal cell; $I C$, non-ciliated crypt cells; $L D T$, lumen of the digestive tubule; $S D$, secondary duct; $V C$, vacuolated cell. 
is indicated by arrows in Fig. 12. The figure shows length/number plots of the three samples. The Newton population comprises four or possibly five size groups. Regular sampling showed that mature sperm and eggs are present only during early November. Groups one and two are immature. Thus, the size groups are almost certainly year groups, Cochlodesma not living more than 5 years - the majority for only 4 -on this beach. There is a fairly steady increase in length of about $4 \mathrm{~mm}$ per year during the life of the animal.

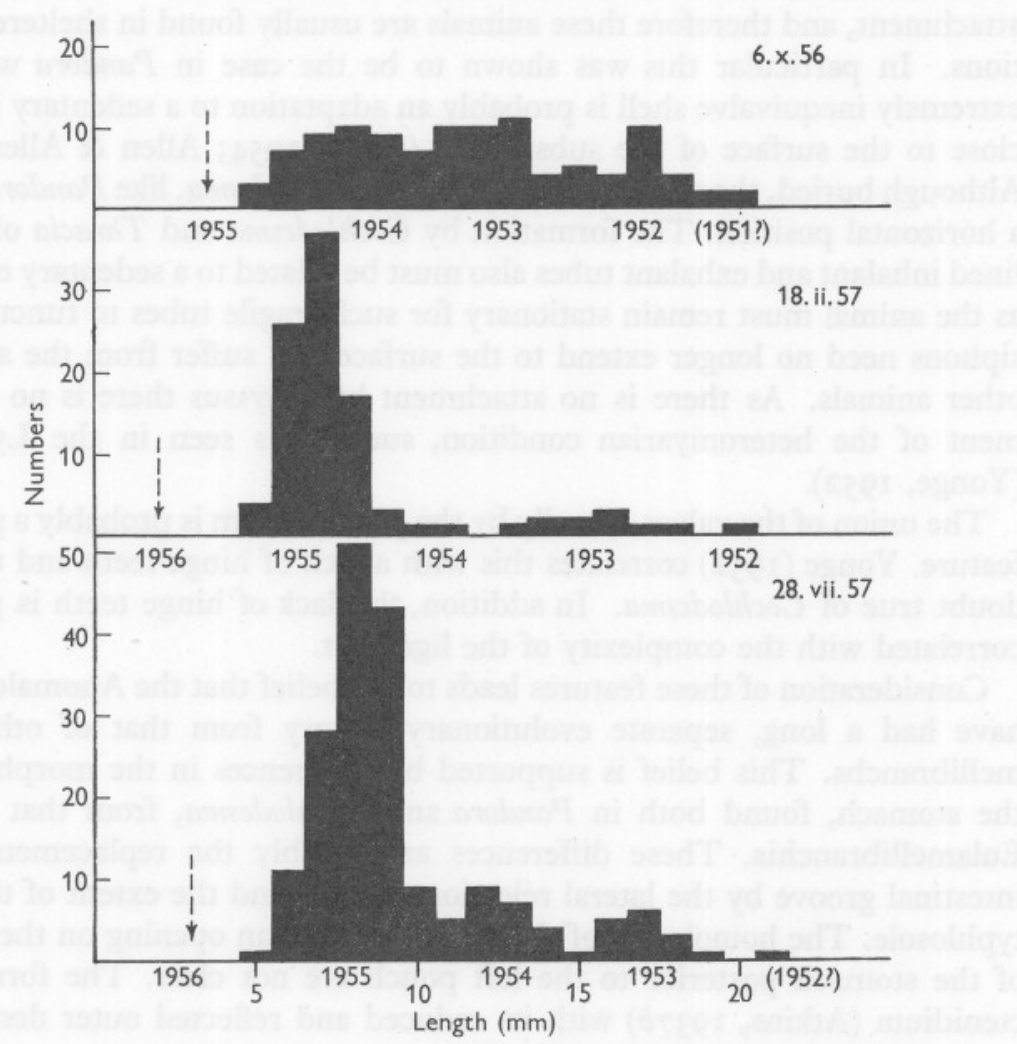

Fig. 12. Histograms of the length/number relationship of samples from the Newton population of Cochlodesma praetenue.

The longest shell recorded was $2 \mathrm{Imm}$. This is by no means large in comparison with shells from the west coast of Scotland. Prof. A. D. Hobson has kindly given me a number of specimens which he collected from the Island of Muck which are between 30 and $32 \mathrm{~mm}$ in length. Forbes \& Hanley (I853) record even larger specimens from deep water off Aberdeen. The specimens from the Island of Muck give no indication whether their growth rate is faster, or whether they live longer than the Northumberland specimens. 


\section{DISCUSSION}

The Anomalodesmata are rarely found in great numbers and must be regarded as being amongst the least successful of Lamellibranchia inhabiting sands and muds. Yonge (1952) emphasized this in his studies on the Lyonsiidae, and showed that in this family there was adaptation for sedentary life. A similar, but less marked tendency toward sedentary life is seen in the related families, Thraciidae, Pandoridae and Laternulidae. There is no byssal attachment, and therefore these animals are usually found in sheltered conditions. In particular this was shown to be the case in Pandora where the extremely inequivalve shell is probably an adaptation to a sedentary life on or close to the surface of the substratum (Allen, I954; Allen \& Allen, 1955). Although buried, the somewhat inequivalve Cochlodesma, like Pandora, adopts a horizontal position. The formation by Cochlodesma and Thracia of mucuslined inhalant and exhalant tubes also must be related to a sedentary existence, as the animal must remain stationary for such fragile tubes to function. The siphons need no longer extend to the surface and suffer from the attacks of other animals. As there is no attachment by a byssus there is no development of the heteromyarian condition, such as is seen in the Lyonsiidae (Yonge, 1952).

The union of the valves dorsally by the periostracum is probably a primitive feature. Yonge (1952) correlates this with a lack of hinge teeth and this is no doubt true of Cochlodesma. In addition, this lack of hinge teeth is probably correlated with the complexity of the ligament.

Consideration of these features leads to the belief that the Anomalodesmata have had a long, separate evolutionary history from that of other eulamellibranchs. This belief is supported by differences in the morphology of the stomach, found both in Pandora and Cochlodesma, from that in other Eulamellibranchia. These differences are notably the replacement of the intestinal groove by the lateral rejection grooves and the extent of the major typhlosole. The homologies of the caecum and of an opening on the left side of the stomach posterior to the left pouch are not clear. The form of the ctenidium (Atkins, I937 $b$ ) with its reduced and reflected outer demibranch again is characteristic of the suborder.

Cochlodesma is highly specialized for a sedentary life in sheltered conditions at low-water mark and below. Although it is closely related to the Thraciidae, Pandoridae and Lyonsiidae it possesses characteristics that clearly distinguish it from these related forms.

\section{SUMMARY}

Cochlodesma praetenue is well adapted for a sedentary life in sheltered conditions in soft substrata at low-water mark to a depth of 60 fathoms.

The habits, morphology and ciliary feeding and cleansing mechanisms are 
described and compared with those of members of the related families Thraciidae, Pandoridae and Lyonsiidae.

The complex ligament is described. The mantle edges are extensively fused. The detailed structure of the siphons is described and related to their function of laying down mucus-lined inhalant and exhalant tubes.

The morphology and ciliary currents of the stomach show modifications similar to those previously described for Pandora. These modifications involve the extent of the major typhlosole and the replacement of an intestinal groove by lateral rejection grooves.

Analysis of three large samples shows that Cochlodesma from the Northumberland coast live for a maximum of 5 years. These animals become mature in their third year, spawning in early November.

\section{REFERENCES}

Allen, J. A., 1953. Function of the foot in the Lucinacea (Eulamellibranchia). Nature, Lond., Vol. I71, p. III7.

1954. On the structure and adaptations of Pandora inaequivalvis and P. pinna. Quart. F. micr. Sci., Vol. 95, pp. 473-82.

- (in the Press). On the basic form and adaptations to habitat in the Lucinacea.

Allen, M. F. \& Allen, J. A., I955. On the habits of Pandora inaequivalvis (Linné). Proc. malac. Soc. Lond., Vol. 31, pp. 175-85.

AtKIns, D., 1937a. On the ciliary mechanisms and interrelationships of lamellibranchs. Part II. Quart. F. micr. Sci., Vol. 79, pp. 339-73.

- 1937b. On the ciliary mechanisms and interrelationships of lamellibranchs. Part III. Quart. F. micr. Sci., Vol. 79, pp. 375-42I.

Chapman, G. \& Newell, G. E., I956. The rôle of the body fluid in the movement of soft-bodied invertebrates. II. The extension of the siphons of Mya arenaria L. and Scrobicularia plana (da Costa). Proc. roy. Soc. B, Vol. I45, pp. 564-80.

Forbes, E. \& Hanley, S., 1853. A History of the British Marine Mollusca, and their Shells. London.

Morton, J. E., 1956. The tidal rhythm and action of the digestive system of the lamellibranch Lasaea rubra. F. mar. biol. Ass. U.K., Vol. 35, pp. 563-86.

OlDFIELD, E., I955. Observations on the anatomy and mode of life of Lasaea rubra (Montagu) and Turtonia minuta (Fabricius). Proc. malac. Soc. Lond., Vol. 3I, pp. 226-47.

OwEN, G., I953. On the biology of Glossus humanus (L.) (Isocardia cor Lam.). F. mar. biol. Ass. U.K., Vol. 32, pp. 85-106.

- 1955. Observations on the stomach and digestive diverticula of the Lamellibranchia. I. The Anisomyaria and Eulamellibranchia. Quart. F. micr. Sci., Vol. 96, pp. 517-37.

Owen, G., Trueman, E. R. \& Yonge, C. M., 1953. The ligament in the Lamellibranchia. Nature, Lond., Vol. I7I, p. 73.

RIDEwood, W. G., I903. On the structure of the gills of the Lamellibranchia. Phil. Trans. B, Vol. 195, pp. 147-248.

ThIELE, J., I935. Classis Bivalvia. Handbuch der Systematischen Weichtierkunde, Tl. 3. Jena.

YoNGE, C. M., I926. The digestive diverticula in lamellibranchs. Trans. roy. Soc. Edinb., Vol. 54, pp. 703-I8. 
- 1937. The formation of siphonal openings by Thracia pubescens. Proc. malac. Soc. Lond., Vol. 22, pp. 337-8.

1949. On the structure and adaptations of the Tellinacea, deposit-feeding Eulamellibranchia. Phil. Trans. B, Vol. 234, pp. 29-76.

1952. Studies on Pacific coast mollusks. IV-VI. Structure and adaptation in Entodesma saxicola (Baird) and Mytilimeria nuttallii Conrad, with a discussion on the evolution of the family Lyonsiidae (Eulamellibranchia). Univ. Calif. Publ. Zool., Vol. 55, pp. 439-50.

1957. Mantle fusion in the Lamellibranchia. Pubbl. Staz. zool. Napoli, Vol. 29, pp. I5I-7I. 